\title{
Contribution of Man - Made Activities to the Pollution of the Tigris within Mosul Area/IRAQ
}

\author{
S. M. Al-Rawi ${ }^{{ }^{*}}$ \\ ${ }^{1}$ Head of Pollution Control Section \& Assistant Professor of Environmental, Engineering Environment Research Center \\ (ERR), Mosul University, Mosul/IRAQ. \\ *Correspondence to Dr. S. M. Al-Rawi. Email: alrawism@yahoo.com
}

Received: 10 January 2005 / Accepted: 10 April 2005 / Published: 14 August 2005

\begin{abstract}
This paper presents an overall view of major sources that may lead to the pollution of the Tigris within Mosul city. A stretch exceeding 20kms in length is selected that represents the "sick" path of the river. Many sites along the studied stretch are likely to affect the river quality in some way or another. Samples from 40 sources sites are taken for quality analyses These sources - as huge as $400000 \mathrm{~m}^{3}$ a day - are characterized as (medium - strong) in composition. Such wastewaters with the pollutants they carry alter the river water quality rendering it unsuitable for beneficial uses. Such alterations - do leave -many negative consequences concerning human beings and aquatic life. It is found that domestic discharges are among the most important sources of pollution. Sanitary wastes are often discharged - untreated -into the Tigris. Other illegal practices such as inhouse slaughtering add to the pollution as well. Industrial, tourist and institutional wastes put an additional burden on pollution of the river water quality. These wastes contain lead, chrome, and other heavy metals that may pose health risks. Wastewater treatment plants that exist in some sectors do not perform as they are expected. They need proper evaluation and rehabilitation. Eutrophication - a characteristic problem in lakes - finds an access to occur into the Tigris. This problem results from intensive use of detergents rich in nutrients (P\&N compounds). In general, pollutants of different sources heavily affect the river water. Recovery and self purification of the river is estimated to occur at $40 \mathrm{~km}$ far from reference point. The paper concludes with the necessity of construction of a central treatment plant(s) or tackling the pollutants at their origin. The paper also stresses on importance of environmental education and awareness in order to combat pollution problems.
\end{abstract}

Keywords: Tigris, Surface water Pollution

\section{Introduction}

The Tigris is considered the sole surface water resource in Mosul city/IRAQ. Its water is used for domestic, municipal, industrial, agricultural, and recreational purposes. Besides, the Tigris is thought to be the ultimate sink for all wastewater arising from above activities.

The Tigris had been put under monitoring for years. Many papers and theses were published regarding its sources of pollution, pollutants concentration, degradation in water quality, and other aspects [1-5].

This paper is another effort added to previous works trying to shed light on evaluating status of the river as it passes through a selected stretch within Mosul city. Such stretch includes the major point and non point sources of pollution that do affect river water quality and quantity.

\section{Materials and Methods}

A detailed survey was made to figure out the activities that might contribute to the pollution of the
Tigris within Mosul city (fig 1). More than (60) discharge sites were visited. Samples from (36) sites had been taken for quality characterization. Physical, chemical, and biological tests had been conducted on each adopting "the standard methods" $(6,7)$. Table 1 shows these tests.

Table 1: The Studied Characteristics

\begin{tabular}{ll}
\hline Characteristics & \multicolumn{1}{c}{ Studied Parameters } \\
\hline \multirow{2}{*}{ Physical } & $\begin{array}{l}\text { Turbidity, temperature, total solids } \\
\text { TS, suspended solids SS, total } \\
\text { dissolved solids TDS, color, odor }\end{array}$ \\
\hline \multirow{3}{*}{ Chemical } & $\begin{array}{l}\text { Electrical conductivity EC, pH, } \\
\text { alkalinity Alk., total hardness TH, } \\
\text { chlorides Cl, sulphates } \mathrm{SO}_{4}, \\
\text { Phosphates, } \mathrm{PO}_{4} \text {, organic load in } \\
\text { terms of } \mathrm{BOD}_{5}\end{array}$ \\
\hline Biological & Bacterial counts, chlorophyll \\
\hline
\end{tabular}




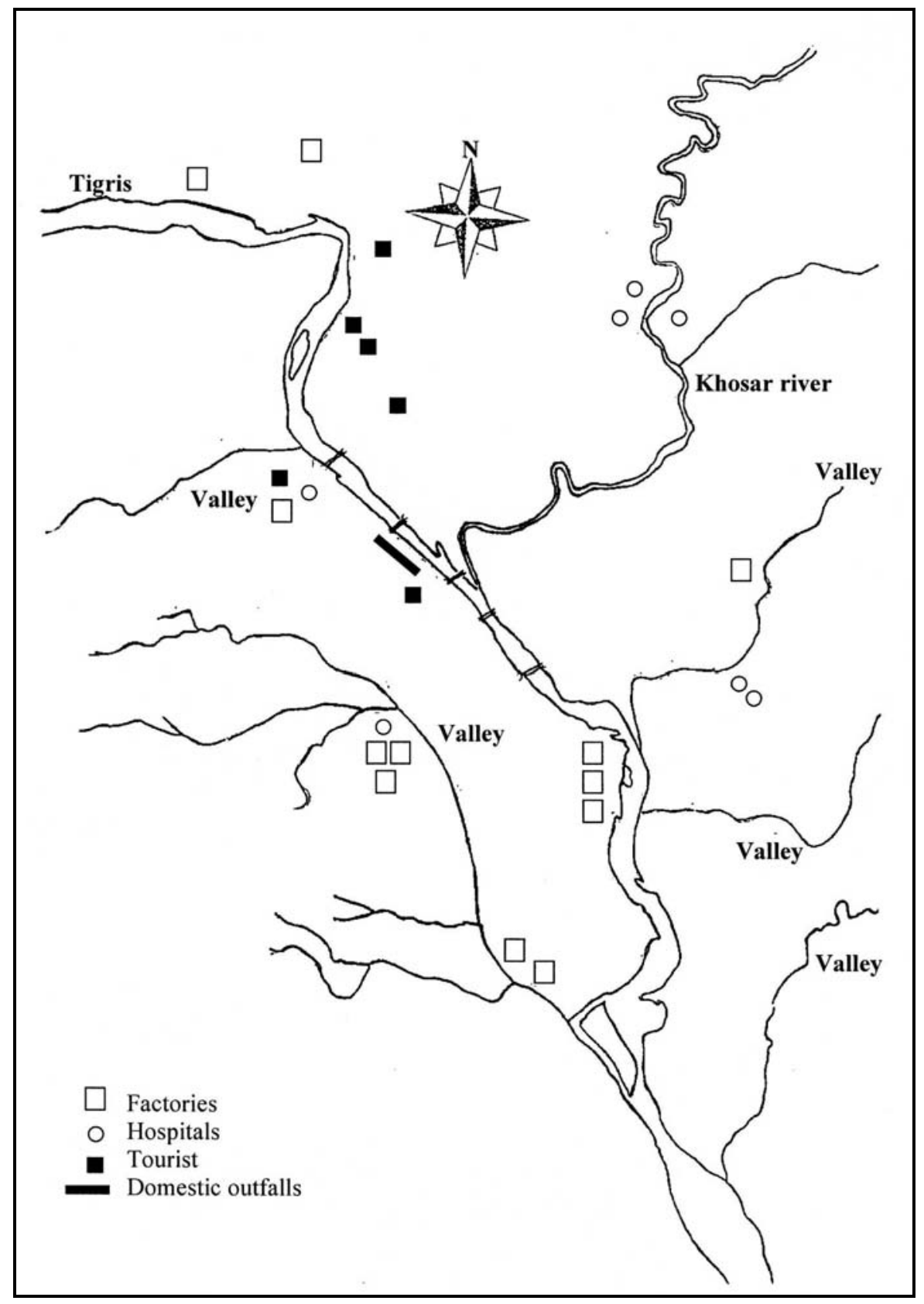

Figure 1: Pollution Sources of the Tigris River within Mosul city 


\section{Results and Discussions}

The Tigris - like any other water resource - is subjected to numerous sources of pollution. Municipal discharges, industrial pollutants, agricultural activities residuals, direct runoff, tourism, illegal practices, atmospheric pollution, and others are few examples. The most important sources covered for the purpose of this paper are listed in table (2).

Table 2: Major Contributor Sites \& Characteristics to the Tigris Pollution

\begin{tabular}{|c|c|c|}
\hline Site & No. & Remarks \\
\hline $\begin{array}{l}\text { Hotels and } \\
\text { Tourist } \\
\text { Establishments }\end{array}$ & 6 & $\begin{array}{l}\text { Some of these sites discharge } \\
\text { their wastes into insecure } \\
\text { septic tanks and may } \\
\text { contaminate ground water due } \\
\text { to seepage. Other sites possess } \\
\text { their own compact waste } \\
\text { treatment plants that often are } \\
\text { shortly operated }\end{array}$ \\
\hline $\begin{array}{l}\text { Hospitals and } \\
\text { Health-Care } \\
\text { Institutions }\end{array}$ & 9 & $\begin{array}{l}\text { Some sites discharge wastes } \\
\text { into sewers connected to the } \\
\text { river or the wastes are } \\
\text { discharged to insecure septic } \\
\text { tanks that may lead in some } \\
\text { way or another to ground } \\
\text { water pollution }\end{array}$ \\
\hline $\begin{array}{l}\text { Industries and } \\
\text { Factories }\end{array}$ & 18 & $\begin{array}{l}\text { Majority of sites discharge their } \\
\text { wastes to storm or domestic } \\
\text { sewers connected to the river. } \\
\text { Some sites discharge the wastes } \\
\text { to lagoons or large pits. The } \\
\text { latter may seep to ground water. } \\
\text { Some industries hope to have } \\
\text { their own treatment plants in the } \\
\text { nearby future. }\end{array}$ \\
\hline Valleys & 6 & $\begin{array}{l}\text { These valleys discharge waste } \\
\text { load into the river directly. These } \\
\text { wastes comprise those generated } \\
\text { due to various domestic and } \\
\text { industrial activities. Such wastes } \\
\text { are sometimes used for } \\
\text { agricultural purposes. }\end{array}$ \\
\hline
\end{tabular}

It is estimated that as huge as $400000 \mathrm{~m}^{3}$ of wastewater is daily discharged - untreated - into the river. This is equivalent to $17000 \mathrm{~m}^{3} / \mathrm{hr}$ with a peak of $20000 \mathrm{~m}^{3} / \mathrm{hr}$ at day hours. Domestic waste loads, on the one hand, add a great burden on the pollution of the Tigris. These wastes comprise foul wastes of more than 6000 dwellings and apartments lacking waste collection system. Considerable amounts of these wastes are directly or indirectly (via valleys) discharge their loads into the river (table 3 )

Table 3: Residential Units Distribution

\begin{tabular}{lcc}
\hline Site & No. of Units & $\begin{array}{c}\text { Location } \\
\text { Relative to } \\
\text { the River }\end{array}$ \\
\hline Al- khadra & 2535 & Left \\
Sugar Mill & 405 & Right \\
Teztile Mill & 1711 & Right \\
Domeez & 800 & Left \\
Prefabricated Building & 206 & Left \\
Al- Yarmook & 404 & Right \\
AL- Mamoon & 100 & Right \\
\hline
\end{tabular}

The field survey reveals that some of the pollution sources are direct point sources while some other sources are indirectly affecting the river water quality. As these sources differ, the nature of their pollution loads vary accordingly as shown in tables (4-6). The characteristics of discharged wastewater can be grouped into the medium- strong categories according to guidelines [8]. The tests also verify that a clear deterioration in water quality does occur. Concentration of various contaminants \& compounds exceed the limits recommended by local and authorized agencies $[9,10]$.

Odor, foam, color, death and migration of aquatic life, and dominance of anaerobic conditions can easily be detected near sewer outfalls. These adverse consequences as well as the increase of pollutant concentrations have lessen the river aesthetics, increase hardness, salinity, and rendering the water unfit for different beneficial uses.

Table 4: Characteristics of Domestic Wastes

\begin{tabular}{lccccc}
\hline Character & Domestic & Al-khosar & Character & Domestic & A-khsarl \\
\hline $\mathrm{pH}$ & $6.99-7.41(7.31)$ & $7.32-7.91(7.53)$ & $\mathrm{Cl}$ & $26-98(55.3)$ & $45-56(49)$ \\
$\mathrm{EC}$ & $647-1043(736)$ & $880-1043(943)$ & $\mathrm{SO}_{4}$ & $190-370(233)$ & $60-375(167)$ \\
$\mathrm{TS}$ & $400-859(667)$ & $726-1880(997)$ & $\mathrm{PO}_{4}$ & $1.1-10.5(7.4)$ & $2.18-39(12.5)$ \\
SS & $110-460(175)$ & $60-120(61)$ & $\mathrm{NO}_{3}$ & $0.37-1.8(0.91)$ & $0.4-1.05(0.69)$ \\
Alk. & $140-240(214)$ & $200-265(232)$ & $\mathrm{BOD}$ & $56-130(69)$ & $65-150(72)$ \\
TH & $270-520(387)$ & $440-660(520)$ & $\mathrm{COD}$ & $103-190(124)$ & $84-247(135)$ \\
\hline
\end{tabular}


Table 5: Characteristics of Industrial Wastes

\begin{tabular}{lccccc}
\hline Character & Food & Textiles & Character & Food & Textiles \\
\hline $\mathrm{pH}$ & $7.24-9.44(7.76)$ & $6.9-7.63(7.19)$ & $\mathrm{Cl}$ & $34-114(45.6)$ & $30-102(52)$ \\
$\mathrm{EC}$ & $500-722(584)$ & $462-642(522)$ & $\mathrm{SO}_{4}$ & $62-320(136)$ & $70-173(103)$ \\
$\mathrm{TS}$ & $435-1298(851)$ & $322-780(531)$ & $\mathrm{PO}_{4}$ & $0.2-0.3(0.21)$ & $1-1.15(1.01)$ \\
$\mathrm{SS}$ & $50-152(73)$ & $82-240(120)$ & $\mathrm{NO}_{3}$ & $0.9-1.39(1.01)$ & $0.8-3.2(1.22)$ \\
Alk. & $75-340(166)$ & $145-500(236)$ & $\mathrm{BOD}$ & $81-848(588)$ & $100-190(135)$ \\
$\mathrm{TH}$ & $115-340(249)$ & $190-420(277)$ & $\mathrm{COD}$ & $90-1123(409)$ & $185-410(235)$ \\
\hline
\end{tabular}

- All units are in mg/l except pH .EC in micromhos/cm, TH, and Alkalinity in mg/l as $\mathrm{CaCO}_{3}$.

- Values between brackets represent the mean value

Table 6: Characteristics of Valleys Wastes

\begin{tabular}{lccccc}
\hline Character & Eqab Valley & Danfeely Valley & Character & Eqab Valley & Danfeely Valley \\
\hline pH & $7.24-7071(7.35)$ & $7.3-7.8(7.51)$ & $\mathrm{Cl}$ & $31-65(36.8)$ & $34-42(37.8)$ \\
EC & $570-689(630)$ & $636-802(735)$ & $\mathrm{SO}_{4}$ & $40-260(175)$ & $80-250(140)$ \\
TS & $482-2400(839)$ & $522-860(697)$ & $\mathrm{PO}_{4}$ & $2.6-4.8(4.05)$ & $2.5-8.4(5.37)$ \\
SS & $58-600(180)$ & $89-260(131)$ & $\mathrm{NO}_{3}$ & $0.27-1.50(0.59)$ & $0.9-1.5(1.06)$ \\
Alk. & $160-200(176)$ & $170-260(215)$ & $\mathrm{BOD}$ & $43-110(56.6)$ & $30-106(55.1)$ \\
TH & $272-300(288)$ & $348-500(383)$ & $\mathrm{COD}$ & $54-153(99.3)$ & $70-152(112.8)$ \\
\hline
\end{tabular}

The changes in the physical characteristics of the river water such as temperature, turbidity, and suspended solids are clearly demonstrated in table 7 . These changes are detected as the river passes along the stretch of the study area. In the north of the city there exists a large water impoundment. Some quarries and constructional mills are encountered. Animal breeding (buffalo, sheep and cows) are widespread. In the heart of the city there are more than 15 point sources discharging their loads into the river. It is strongly stressed that such activities will continue deteriorating the river water quality.

Table 7: Major Human Activities Affecting the Physical Characteristics of the River

\begin{tabular}{|c|c|c|c|}
\hline Activity & Temperature & Turbidity & $\begin{array}{l}\text { Suspended } \\
\text { Solids }\end{array}$ \\
\hline $\begin{array}{l}\text { Cooling } \\
\text { Processes } \\
\text { Domestic }\end{array}$ & ++ & & \\
\hline $\begin{array}{l}\text { Sewage } \\
\text { Discharges } \\
\text { Industrial }\end{array}$ & + & + & + \\
\hline $\begin{array}{l}\text { Wastewater } \\
\text { Discharges }\end{array}$ & + & ++ & ++ \\
\hline $\begin{array}{l}\text { Agricultural } \\
\text { Activities }\end{array}$ & + & +++ & +++ \\
\hline Navigation & & ++ & ++ \\
\hline Dredging & & ++ & ++ \\
\hline
\end{tabular}

+ Slight Increase; + + Clear Increase; + + + Severe Increase.
One of the most important sources of pollution is the domestic discharges. Such wastes render the river water unfit for beneficial uses. Previous studies [11] revealed that the river water is no longer valid for swimming. The total bacterial count in the discharged wastewater is amounted as high as $2 \times 10^{4}-2 \times 10^{7}$. These amounts exceed the recommended values [12]. This disorder is attributed to some illegal practices such as discharging toilet waste directly into the river or due to in-house slaughtering activities.

Eutrophication, a phenomenon that largely takes place at lakes and slow moving water bodies has found an access to occur in the Tigris. This problem arises from the fact of using large amounts of nutrient- rich detergents. Throughout the past years, detergents were distributed to the families as a part of a monthly ration of oil for food program during sanction (1991-present). Such detergents contained high concentrations of phosphorous the main cause of eutrophication, (see table 8).

Table 8: Components of Used Detergents as a Part of Family Ration.

\begin{tabular}{lc}
\hline Component & Percentage \\
\hline Active Ingredients & $24 \%$ \\
Multisodium Phosphates & $30 \%$ \\
Sodium Silicates & $8 \%$ \\
Sodium Sulphates & $26 \%$ \\
Perfumes & $(0.1-0.3) \%$ \\
\hline
\end{tabular}


Moreover, eutrophication can be detected by chlorophyll measurement which surpasses the guidelines of $2 \mathrm{mg} / \mathrm{l}$ [13]. Eutrophication is known of its vast adverse effects, some of which are listed in table (9). The $\mathrm{BOD}_{5}$ values represent the organic pollution of the Tigris. Organic load leads to decline of dissolved Oxygen and release of ammonia and nitrite. This declination may extend for tens of kilometers.

Table 9: Some Problems Caused by Eutrophication

\begin{tabular}{ll}
\hline $\begin{array}{l}\text { Economic loss due to } \\
\text { tourism decline and } \\
\text { polluted river water }\end{array}$ & $\begin{array}{l}\text { Increase in heavy metal } \\
\text { concentration }\end{array}$ \\
$\begin{array}{l}\text { Fluctuation of dissolved } \\
\text { oxygen concentration } \\
\text { during day and night }\end{array}$ & $\begin{array}{l}\text { Increase of chlorination } \\
\text { doses that may cause } \\
\text { cancer }\end{array}$ \\
$\begin{array}{l}\text { Turbidity increase } \\
\text { Disturbance of } \\
\text { flocculation process } \\
\text { Corrosion of pipes, } \\
\text { Increase of bacterial } \\
\text { growth }\end{array}$ & $\begin{array}{l}\text { reservoirs and facilities } \\
\text { Clogging of filters in }\end{array}$ \\
Water treatment plants & Odor, color, and taste \\
\hline
\end{tabular}

Table (10) illustrates BOD variations along the studied stretch. This table indicates that river water can be classified as poor- good in terms of quality as per authorized standards [14]. It does show that the Tigris starts recovering its health after $40 \mathrm{~km}$.

Table 10: $\mathrm{BOD}_{5}$ Variation along the Studied Stretch

\begin{tabular}{|c|c|c|c|}
\hline$\stackrel{\Xi}{5}$ & 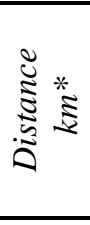 & 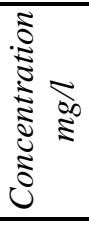 & 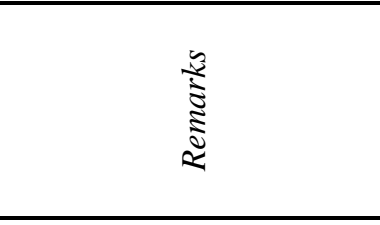 \\
\hline Unified WTP & 0.00 & 2.7 & River entrance to Mosul city \\
\hline Bridge 3 & 8.0 & 3.3 & $\begin{array}{l}\text { Industrial activities } \\
\text { predominate. A valley } \\
\text { discharges its load of } \\
\text { domestic \& industrial } \\
\text { pollutants directly into the } \\
\text { Tigris } \\
\text { Human \& man-made } \\
\text { activities through } 20\end{array}$ \\
\hline Bridge 4 & 11 & 3.2 & $\begin{array}{l}\text { outfalls appear to affect } \\
\text { the river quality in this } \\
\text { location }\end{array}$ \\
\hline Albosaif & 18 & 34 & $\begin{array}{l}\text { Very polluted valleys and } \\
\text { other main box sewer as } \\
\text { well as sugar mill \& } \\
\text { tanneries discharge their } \\
\text { load of pollution in this } \\
\text { stretch. }\end{array}$ \\
\hline Qunetra & 34 & 3.00 & $\begin{array}{l}\text { The river starts self } \\
\text { purification and recovers } \\
\text { its aesthetics. }\end{array}$ \\
\hline
\end{tabular}

\footnotetext{
* Reference Point
}

On the other hand, the survey revealed the huge adverse impacts incurred by industry, tourism and health-care institutions. Most of local industries have no wastewater treatment plants. Wastes are directly discharged untreated into the Tigris. Most of existing wastewater treatment plants do not perform as expected. Moreover, such plants are secondary and incapable of removing nutrients ( $\mathrm{P} \& \mathrm{~N}$ compounds) as well as they poorly perform at shock loads occasions. Table (11) shows the performance of some plant covered by the survey.

Table 11: Wastewater Treatment Plants Performance

\begin{tabular}{lcccc}
\hline Plant Site & $\begin{array}{c}\text { Effluent } \\
\text { SS } \\
(\mathrm{mg} / \mathrm{L})\end{array}$ & $\begin{array}{c}\% \\
\text { Removal }\end{array}$ & $\begin{array}{c}\text { Effluent } \\
\text { BOD } \\
(\mathrm{mg} / \mathrm{L})\end{array}$ & $\begin{array}{c}\% \\
\text { Removal }\end{array}$ \\
\hline $\begin{array}{l}\text { Neneva } \\
\text { Hotel }\end{array}$ & $17-200$ & $12-66$ & $30-93$ & $5-63$ \\
$\begin{array}{l}\text { Khansa } \\
\text { Hospital }\end{array}$ & $22-65$ & $13-87$ & $23-150$ & $14-62$ \\
$\begin{array}{l}\text { Al-Salam } \\
\text { Hospital }\end{array}$ & $23-91$ & $40-96$ & $6-24$ & $75-90$ \\
$\begin{array}{l}\text { Mosul } \\
\text { Hotel }\end{array}$ & $80-112$ & $11-23$ & $10-30$ & $50-90$ \\
$\begin{array}{l}\text { Hospital } \\
\text { Complex }\end{array}$ & $38-200$ & $33-72$ & $11-22$ & $76-90$ \\
$\begin{array}{l}\text { Food } \\
\text { Industries }\end{array}$ & $50-500$ & $3-50$ & $36-220$ & $30-66$ \\
\hline
\end{tabular}

Heavy metals such as chrome, copper, and arsenic may have an access to reach the river. Some industries produce these elements in their processes like textiles industries, tanneries, etc. Al -Layla \& Al-Rawi confirm this fact upon studying impact of textile wastewater discharges on the Tigris [15]. Lead concentrations may increase in the river water. This element arises from traffic and reaches the river from runoff or via atmosphere. The problem with heavy metal is that they are absorbed by particulates at normal $\mathrm{pH}$ levels causing very low dissolved traces and consequently its monitoring becomes very complicated [16].

\section{Conclusions}

(1) The Tigris river water quality shows a distinct deterioration within the studied stretch . Point and non- point sources of pollution are widespread along the selected stretch.

(2) Domestic wastewater discharges and illegal practices severely affect the Tigris water quality. This is reflected on an increase in organic \& bacterial loads, and causing health risks.

(3) Industrial, tourism, medical institutions and other services add to the pollution of the river impeding self purification and rendering the water unfit for different uses.

(4) Reduced performance of waste treatment plants accompanied by the lack of specialized operators.

(5) The increased consumption of detergents increased occurrence of eutrophication. 
(6) The Tigris starts recovering health and resumes an acceptable quality after $40 \mathrm{~km}$ from reference point.

(7) Absence of awareness of the pollution prevention measures and the non-existing of a real environmental monitoring authority increased pollution of the Tigris.

\section{Recommendations}

(1) Water and sewerage directorates should play an effective role in preventing unlawful connections to water networks and reducing hydraulic loads received by the river.

(2) Environmental authority should be given the power to enforce the law against illegal practices.

(3) All types of media should contribute to raise the public awareness of environmental protection as a holy and human task recommended by all religions (Islam, Christianity, etc).

\section{References}

1. Scientific Consulting Bureau: "Causes of Algal Bloom in the Tigris". College of Science, Mosul University, 1999, 115 pages (Arabic Text).

2. Ali L. Hameed, Obeid F Ahmad, and Mohammad S. Ali: "Some Sources of Water Pollution by Agricultural \& Industrial Wastes”. Education \& Science J., 1989, Vol 8, 57-68 (Arabic Text).

3. Al- Rawi, S .Mahmoud: "Some Pollution Aspects of The Tigris within Mosul City". Environ. \& Sustainable Development J., 1999, Vol. 2, No.1, 8696, (Arabic Text).

4. Taleea A Younis: "Pollution of the Tigris by Industrial \& Domestic wastes south of Mosul" Education \& Science J., 1999, No. 35, 51-59 (Arabic Text).
5. Al-Nima B Ali, Nassori G, and Al -Dabbagh A Ghanim: "Impact of Low Precipitation on the Tigris Quality”, Al-Rafidain Sciences J., 2000, Vol.2 No.2, 45-56(Arabic Text).

6. Abbawi, S Abid and Hassan, M. S.: "Environmental Engineering Water Analysis” Mosul Univ. Publishing House, 1990, 296 pages. (Arabic Text).

7. APHA, AWWA, and WPCF: "Standard Methods for the Examination of Water and Wastewater" 14 ed., 1985, 1193 pages.

8. Metcalf \& Eddy Inc.: "Wastewater Engineering Treatment, Disposal, and Re- Use" Tata McGraw Hill Pub. Co. $2^{\text {nd }}$ ed., 1985, 920 pages.

9. Lamb J .C: “Water Quality and Its Control” John Wiley \& Sons, 1985, 384 pages.

10. Ministry of Health: "Environmental Legislation" 1988, 22 pages (Arabic Text).

11. Naoom J Zeki: "Impact of Mosul City Wastewater Discharges upon the Tigris” MSc. thesis Mosul Univ., 1985, 126 pages (Arabic Text).

12. WHO: "Our Planet, Our Health” Geneva, 1992, 282 pages.

13. Al- Singery M. N: “An Ecological study of the Tigris within Mosul City” MSc thesis Mosul Univ., 2001, 141 pages, (Arabic Text).

14. Mohammad, Al-Shawani T.: "An Ecological and Environmental Study of Al-Zab River at Alton Kobri" MSc thesis, College of Education, Tikrit University, 2001, 131 pages.

15. Al-Layla, M. Anis; Al-Rawi, S M.: "Impact of Textile Factory Effluents on Tigris river water quality” Environ. Health \& Engineering r. Part A, Environmental. Science \& Engineering, USA, 1988, A23, No.6, 559-568,

16. UNESCO, WHO, and UNDP: "Water Quality Assessment” Chapman \& Hall Pub. Co., 1992, $1^{\text {st }}$ edition, pp.585. 